\title{
UNSUR KOHESI PADA NASKAH DRAMA SENJA DENGAN DUA KELELAWAR DAN PEMANFAATANNYA DALAM PEMBELAJARAN SASTRA DI SEKOLAH MENENGAH ATAS
}

\author{
Abdullah Lathifudin, Sarwiji Suwandi, Muhammad Rohmadi \\ Universitas Sebelas Maret \\ Email: bastindlathief@gmail.com
}

\begin{abstract}
Abstrak: Penelitian ini bertujuan untuk mendeskripsikan: (1) peranti kohesi pada naskah drama Senja dengan Dua Kelelawar karya Kirdjomuljo, dan (2) relevansi peranti kohesi pada naskah drama Senja dengan Dua Kelelawar dengan pembelajaran bahasa Indonesia di SMA. Penelitian ini merupakan penelitian kualitatif kebahasaan dengan metode analisis isi. Sumber data yang digunakan adalah dokumen dan informan. Teknik pengambilan sampel menggunakan teknik purposive sampling. Teknik pengumpulan data menggunakan metode simak dan wawancara. Validitas data dilakukan dengan triangulasi teori dan triangulasi sumber data. Analisis data menggunakan teknik analisis interaktif. Hasil penelitian menunjukkan: (1) peranti kohesi yang terdapat pada naskah drama Senja dengan Dua Kelelawar meliputi kohesi gramatikal dengan subjenis (a) pronomina, (b) penyulihan, dan (c) pelesapan, kohesi leksikal dengan subjenis (a) pengulangan, (b) sinonimi, (c) hiponimi, (d) meronimi, dan (e) kolokasi, dan konjungsi dengan subjenis (a) konjungsi koordinatif, dan (b) konjungsi subordinatif. Unsur yang paling dominan adalah pronomina dan konjungsi; (2) peranti kohesi pada naskah drama Senja dengan dua Kelelawar memiliki relevan dengan pembelajaran bahasa Indonesia khususnya materi tentang unsur kebahasaan teks pada kelas X, kelas XI, dan kelas XII SMA.
\end{abstract}

Kata kunci: peranti kohesi, naskah drama Senja dengan Dua Kelelawar, pembelajaran bahasa Indonesia

\section{ELEMENTS OF COHESION IN "SENJA DENGAN DUA KELELAWAR" PLAY SCRIPT AND ITS USE IN LITERATURE LEARNING AT SENIOR HIGH SCHOOL}

\begin{abstract}
This study aims to describe: (1) cohesive devices in drama script Senja dengan Dua Kelelawar by Kirdjomuljo, and (2) the relevance of cohesive devices on drama script Senja dengan Dua Kelelawar with Indonesian language learning in high school. This research is linguistic qualitative research with content analysis method. The data sources used are documents and informants. The sampling technique uses purposive sampling technique. Data collection techniques use scrutinize method and interview method. Data validity is done by theory triangulation and data source triangulation. Data analysis using interactive analysis techniques. The results of the study show: (1) cohesive devices found in drama script Senja dengan Dua Kelelawar covering grammatical cohesion with sub-types (a) pronouns, (b) recovery, and (c) lapse, lexical cohesion with subtitles $(a)$ repetition, $(b)$ synonym, $(c)$ hyponym, $(d)$ meronym, and (e) collocation, and conjunction with sub-types (a) coordinative conjunctions, and (b) subordinate conjunctions. The most dominant elements are pronouns and conjunctions; (2) cohesion devices in drama scripts Senja dengan Dua Kelelawar have relevance to Indonesian language learning, especially material about the linguistic elements of text in $10^{\text {th }}$ grade, $11^{\text {th }}$ grade, and $12^{\text {th }}$ grade high school.
\end{abstract}

Keywords: cohesion devices, drama script Senja dengan Dua Kelelawar, Indonesian language learning

BASASTRA Jurnal Bahasa, Sastra, dan Pengajarannya

Volume 8 Nomor 1, April 2020, P-ISSN 2302-6405, E-ISSN 2714-9765 


\section{PENDAHULUAN}

Bahasa Indonesia merupakan salah satu mata pelajaran yang wajib dipelajari dan dikuasai oleh peserta didik. Mata pelajaran bahasa Indonesia termasuk salah satu mata pelajaran yang memiliki prioritas lebih tinggi dalam pembelajaran dibanding dengan mata pelajaran lain. Hal ini dapat dilihat dari banyaknya jam pelajaran bahasa Indonesia pada tiap minggunya. Pembelajaran bahasa Indonesia mencakup dua materi pokok, yakni materi tentang kebahasaan dan kesastraan. Di dalam materi kesastraan terdapat kompetensi dasar yang membahas tentang berbagai jenis karya sastra, salah satunya adalah naskah drama. Selain itu, naskah drama wajib dipelajari oleh siswa karena terdapat dalam kompetensi dasar yang harus dikuasai siswa.

Berkaitan dengan hal tersebut, penelitian ini sangat penting dilakukan mengingat penggunaan karya sastra khususnya naskah drama sebagai bahan ajar bahasa Indonesia masih kurang maksimal penggunaannya dalam pembelajaran. Di sekolah, naskah drama merupakan karya sastra yang paling tidak diminati oleh peserta didik dibandingkan karya sastra lain seperti prosa dan puisi (Waluyo, 2003: 1). Penyebab rendahnya minat peserta didik dalam mempelajari drama khususnya naskah drama adalah penghayatan naskah yang berupa dialog yang dinilai cukup sulit dan harus ditekuni. Solusi yang dapat ditempuh untuk menyelesaikan persoalan tersebut adalah dengan menggunakan sumber belajar khususnya naskah drama yang disesuaikan dengan pemahaman dan kebutuhan siswa berdasarkan jenjang dan tahap perkembangannya. Selain pemilihan naskah yang sesuai, strategi pembelajaran yang jitu juga dibutuhkan untuk menumbuhkan minat peserta didik dalam mengapresiasi naskah drama.

Sebagai salah satu jenis karya sastra, naskah drama dapat dijadikan sebagai bahan penelitian khususnya untuk tujuan pendidikan. Naskah drama dapat diteliti dengan beberapa pendekatan sastra. Pendekatan sastra untuk penelitian karya sastra yakni psikologi sastra, sosiologi sastra, semiotik, dan lain sebagainya. Penelitian naskah drama dengan pendekatan sosiologi sastra pernah dilakukan oleh Beding (2015). Dalam penelitiannya, ditemukan bahwa naskah drama tersebut terdapat nilai positif yang dapat dijadikan sumber pembelajaran bagi siswa. Nilai tersebut yakni tentang bagaimana sikap manusia yang harus peka dengan permasalahan di sekitarnya. Selain itu, terdapat nilai sosial yang lain tentang bagaimana cara untuk menyikapi persoalan hidup yang timbul akibat dikekangnya hak asasi manusia. Dari penjelasan di atas dapat disimpulkan bahwa, melalui pendekatan sosiologi sastra naskah drama dapat digunakan sebagai bahan ajar di sekolah.

Penelitian tentang naskah drama yang lain juga pernah dilakukan oleh Wicaksono, dkk., (2018) yang mengkaji naskah drama dengan menggunakan pendekatan psikologi sastra. Hasil dari penelitian menunjukkan bahwa naskah drama sangat layak digunakan sebagai bahan ajar untuk siswa sekolah menengah atas. Naskah drama tersebut mengandung nilai-nilai kehidupan yang sesuai dengan tujuan pendidikan karakter bagi peserta didik. Selain itu, kecocokkan dan latar belakang budaya yang terdapat pada naskah drama tersebut masih sesuai dengan pembelajaran sekarang. Dari segi kebahasaan, bahasa yang digunakan dalam naskah drama mudah dipahami oleh siswa. Terdapat diksi-diksi baru yang dapat menambah wawasan kebahasaan peserta didik. Ungkapan yang digunakan dalam naskah drama juga mudah untuk dicerna.

Dari beberapa hasil penelitian yang mengkaji naskah drama dengan pendekatan yang berbeda, maka penulis mencoba untuk meneliti naskah drama dari aspek yang lain. Penulis tertarik untuk meneliti unsur kebahasaan naskah drama. Dengan demikian, naskah drama tidak hanya dimanfaatkan sebagai bahan ajar 
apresiasi sastra saja melainkan juga dimanfaatkan untuk bahan ajar bahasa. Penulis memilih untuk mengkaji peranti kohesi dalam naskah drama yang berjudul Senja dengan Dua Kelelawar karya Kirdjomuljo. Pemilihan naskah tersebut sesuai dengan tujuan penelitian ini yakni mengoptimalkan penggunaan karya sastra sebagai bahan ajar bahasa dan sastra di sekolah menengah atas. Pada objek penelitiannya, penulis memfokuskan untuk meneliti aspek kohesi pada naskah drama tersebut. Data hasil penelitian Wicaksono, dkk., (2018) mengenai kebahasaan dalam naskah drama Senja dengan Dua Kelelawar karya Kirdjomuljo menunjukkan bahwa bahasa yang digunakan ringan dan mudah dipahami. Selain itu, bahasa yang digunakan tetap mengutamakan ketersampaian pesan cerita kepada pembaca melalui keindahan kata. Hal tersebut tentu erat kaitannya dengan bagaimana peranti kohesi yang digunakan untuk menyusun naskah drama tersebut menjadi wacana yang utuh. Oleh karena itu, melalui penelitian ini diharapkan naskah drama Senja dengan Dua Kelelawar karya Kirdjomuljo dapat digunakan secara optimal dalam pembelajaran bahasa Indonesia di SMA.

\section{METODE PENELITIAN}

Penelitian ini adalah merupakan penelitian dengan pendekatan kualitatif kebahasaan. Pendekatan tersebut digunakan karena data penelitian berupa kumpulan kata-kata yang harus dideskripsikan dan diuraikan untuk memperoleh fakta-fakta terkait fenomena yang akan diteliti. Dalam hal ini, pendekatan penelitian digunakan untuk meneliti penggunaan bahasa berupa prolog, dialog, dan petunjuk lakon pada naskah drama Senja dengan Dua Kelelawar karya Kirdjomuljo dan relevansinya dengan pembelajaran bahasa Indonesia di SMA. Metode yang digunakan adalah metode analisis isi.Analisis isi adalah metode ilmiah untuk mempelajari dan menarik kesimpulan atas suatu fenomena dengan memanfaatkan dokumen atau teks (Eriyanto, 2011: 10).

Data dalam penelitian ini adalah hasil analisis dokumen naskah drama Senja dengan Dua Kelelawar karya Kirdjomuljo sesuai dengan permasalahan yang telah dirumuskan. Sumber data yang digunakan adalah dokumen naskah drama dan informan. Informan dalam penelitian ini adalah guru bahasa Indonesia dan peserta didik kelas XI SMA.

Teknik pengambilan sampel yang digunakanadalah teknik purposivesampling. Teknik purposive sampling adalahcara pengambilan sampel data dengan pertimbangan tertentu (Sugiyono, 2016: 53-54). Teknik pengumpulan data dalam penelitian ini adalah dengan metode simak dan wawancara.

Validitas data yang digunakan dalam penelitian ini adalah dengan teknik triangulasi. Triangulasi data digunakan digunakan sebagai proses memantapkan derajat kepercayaan (kredibilitas) dan konsistensi (reliabilitas) data, serta bermanfaat juga sebagai alat bantu analisis data di lapangan (Gunawan, 2015: 218). Triangulasi yang digunakan dalam penelitian ini adalah triangulasi teori dan triangulasi sumber data.

Teknik analisis data yang digunakan pada penelitian ini adalah teknik analisis model interaktif. Koponen-komponen model analisis interaktif meliputi: (1) reduksi data, (2) display data/penyajian data, dan (3) penarikan simpulan (Miles, Huberman, dan Saldana, 2014).

\section{HASIL DAN PEMBAHASAN}

\section{Peranti Kohesi Gramatikal}

Berdarkan hasil dari penelitian yang telah dilakukan, diperoleh bahwa terdapat berbagai jenis peranti kohesi gramatikal, yaitu pronomina, penyulihan, dan pelesapan. Hasil temuan peranti kohesi gramatikal pada naskah drama Senja dengan Dua Kelelawar karya Kirdjomuljo dapat diamati pada tabel 1 . 
Tabel 1.

Temuan Peranti Kohesi Gramatikal

\begin{tabular}{cccc}
\hline No. & $\begin{array}{c}\text { Kohesi } \\
\text { Gramatikal }\end{array}$ & $\begin{array}{c}\text { Jumlah } \\
\text { Temuan }\end{array}$ & $\begin{array}{c}\text { Persen- } \\
\text { tase } \\
(\%)\end{array}$ \\
\hline 1. & Pronomina & 620 & 94,37 \\
2. & Penyulihan & 3 & 0,46 \\
3. & Pelesapan & 34 & 5,17 \\
\hline & Jumlah & 657 & $100 \%$ \\
\hline
\end{tabular}

Pada tabel di atas, diketahui bahwa peranti kohesi gramatikal yang paling banyak ditemukan adalah pronomina, yakni sebanyak 620 bentuk atau 94,37\% Sementara itu, peranti kohesi gramatikal paling sedikit adalah penyulihan, yakni sejumlah 3 bentuk atau $0,46 \%$. Contohcontoh bentuk kohesi gramatikal akan dijabarkan pada subbab berikut.

\section{Pronomina}

Pronomina adalah kelompok kata yang digunakan untuk menggantikan sesuatu yang bersifat benda (Noviastuti, dkk., 2017: 49). Alwi, dkk., (2003: 249). membedakan pronomina menjadi tiga jenis, yaitu pronomina persona, pronomina penunjuk, dan pronomina penanya. Contoh-contoh penggunaan kohesi gramatikal pronomina dapat diamati pada kutipan berikut.

Marsudi : "Itu rumah saya, Nak".

"Kapan-kapan mampirlah, nama saya Marsudi."

Sulaiman: "Saya Sulaiman." (Kirdjomuljo, 2006:26).

Kutipan tersebut merupakan contoh penggunaan pronomina persona. pronomina persona adalah kata ganti atau pronomina yang digunakan untuk mengganti nomina berupa orang atau yang diorangkan (Chaer, 2008: 88). Pada kutipan tersebut dijelaskan bahwa Marsudi dan Sulaiman baru saja saling bertemu dan berkenalan. Marsudi menunjukkan rumahnya dan mempersilakan Sulaiman untuk mampir. Pada kutipan tersebut, terdapat pronomina persona saya yang dipakai oleh keduanya baik Marsudi maupun Sulaiman. Pemakaian pronomina saya oleh Marsudi maupun Sulaiman untuk menggantikan diri masing-masing disebabkan karena mereka baru saja saling mengenal. Selain itu, penggunaan pronomina saya juga digunakan untuk saling menghormati tanpa melihat selisih umur, walapun dengan jelas bahwa Marsudi lebih tua dari Sulaiman. Hal tersebut dapat dilihat dari bentuk nak yang dipakai Marsudi untuk menyapa Sulaiman. Tujuan yang lain dari penggunaan pronomina saya adalah sebagai wujud saling menghormati satu sama lain di dalam kelompok masyarakat.

Bentuk pronomina yang lain adalah pronomina penunjuk. Pronomina penunjuk adalah kata ganti yang dipakai untuk menggantikan nomina sekaligus dengan penunjukkan (Chaer, 2008: 90). Contoh penggunaan pronomina penunjuk dapat diamati pada kutipan berikut.

$$
\begin{aligned}
\text { Ismiyati } & \text { :Pesan Pak Dikun supaya } \\
& \text { dihabiskan saja minuman } \\
& \text { dan makanan ini Pak Sis." } \\
\text { Tomo } & : \text { "O... ya mesti, jangan } \\
& \text { khawatir begitu." } \\
& \text { (Kirdjomuljo, 2006:43). }
\end{aligned}
$$

Pada dialog tersebut dijelaskan bahwa Pak Dikun menitipkan pesan kepada Ismiyati agar makanan dan minuman yang dititipkannya tersebut untuk dihabiskan oleh teman-temannya. Bentuk ini dipakai Ismiyati untuk menunjukan/mengacu makanan dan minuman yang letaknya dekat dengannya. Makanan dan minuman tersebut merupakan unsur di luar teks, sehingga bersifat eksofora.

Bentuk pronomina yang terakhir adalah pronomina penanya. Pronomina penanya adalah kata ganti yang dipakai untuk bertanya maupun untuk menanyakan sesuatu berupa nomina atau bentuk konstruksi nominal (Chaer, 2008: 90). Contoh penggunaan pronomina penanya dapat diamati pada kutipan berikut ini. 
Mursiwi : "Aku akan menjemput Mas Warto."

Siswo :"Aku terus saja, Mur."

Ismiyati : "Kenapa tergesa-gesa, Pak Sis?"

Siswo : "Ada perlu dengan Pak Kepala."

"Kau tidak menjemput di sana saja, Mur?"

(Kirdjomuljo, 2006: 21).

Pada kutipan dialog tersebut dijelaskan bahwa Siswo berusaha untuk mencegah perbuatan Mursiwi yang seperti biasa, menjeput suaminya dan membuat iri perasaan Ismiyati. Karena mengetahui hal itu kemudian Siswo mengajak Mursiwi untuk menjemput Suwarto di sisi lain stasiun. Diketahui terdapat pronomina kenapa yang dipakai Ismiyati untuk menanyakan sesuatu yang menjadi penyebab Pak Sis tergesa-gesa. Acuan dari bentuk tersebut adalah karena Pak Sis ada perlu dengan Pak Kepala, sehingga membuatnya tergesa-gesa khawatir jika Pak Kepala menunggu terlalu lama.

\section{Penyulihan}

Penyulihan adalah proses dan hasil penggantian unsur bahasa oleh unsur bahasa lain yang memiliki satuan lebih besar (Mulyana, 2005: 28). Suwandi menegaskan bahwa, penggantian unsur wacana tersebut haruslah memiliki acuan yang sama dengan unsur sebelumnya dalam sebuah hubungan bentuk-bentuk bahasa (2008: 132). Contoh penyulihan dapat diamati pada kutipan berikut ini.

$\begin{aligned} \text { Marsudi : } & \text { "Aku tahu } \\ \text { penderitaanmu." } & \\ & \text { "Aku tahu kau mencintai }\end{aligned}$

Suwarto, tapi apa gunanya mencintai orang yang sudah beristri?'”

"Ia sudah kawin, tapi kau kepala batu."

(Kirdjomuljo, 2006: 20)

Pada kutipan dialog tersebut dijelaskan bahwa Marsudi memberikan nasihat kepada Ismiyati agar tidak mencintai Suwarto karena ia sudah mempunyai istri. Marsudi menekankan bahwa walaupun Ismiyati berhasil merebut hati Suwarto, hal tersebut hanya akan menghancurkan kehidupan Mursiwi. Diketahui terdapat bentuk penyulihan pada kutipan dialog tersebut. Unsur yang disulih adalah bentuk Suwarto dengan penyulih bentuk orang yang sudah beristri. Kedua unsur tersebut dapat saling menyulih/bersubstitusi karena bentuk orang yang sudah beristri merupakan status yang melekat pada diri Suwarto.

\section{Pelesapan}

Pelesapan adalah adalah penghilangan satuan-satuan kebahasaan (Mulyana, 2005: 28). Sementara itu, Chaer menegaskan bahwa, penghilangan satuan kebahasaan tersebut berupa penghilangan unsur yang sama yang terdapat diantara kalimat-kalimat baik sebelumnya maupun sesudahnya (2009: 227). Pelesapan dapat dikatakan penghilangan atau penyembunyian sebuah bentuk yang sama sebelumnya dengan tanda zero ( $\varnothing)$. Contoh pelesapan dapat diamati pada kutipan berikut ini.

Tomo : "Istri sudah meninggal, tak bisa disesali."

"Cari ø yang lain kalau tidak tahan menjadi duda." (Kirdjomuljo, 2006 :18).

Pada kutipan dialog tersebut dijelaskan bahwa Tomo mengatakan kepada Suwarto untuk mencari pengganti istrinya apabila sudah tidak tahan menjadi duda. Diketahui terdapat pelesapan pada kutipan dialog tersebut. Pelesapan terjadi pada bentuk kalimat tunggal, yaitu pada kalimat kedua. Unsur yang dilesapkan adalah bentuk istri yang terdapat pada kalimat pertama. Unsur zero ( $\varnothing$ ) tersebut menduduki posisi sebagai subjek dalam kalimat kedua. Dengan demikian, apabila ditulis secara lengkap kalimat kedua akan berbunyi "Cari (istri) yang lain kalau tidak tahan menjadi duda". 


\section{Peranti Kohesi Leksikal}

Berdarkan hasil dari penelitian yang telah dilakukan, diperoleh bahwa terdapat berbagai jenis peranti kohesi leksikal, yaitu pengulangan, sinonimi, hiponimi, meronimi, dan kolokasi. Hasil temuan peranti kohesi leksikal pada naskah drama Senja dengan Dua Kelelawar karya Kirdjomuljo dapat diamati pada tabel 2.

Tabel 2.

Temuan Peranti Kohesi Leksikal

\begin{tabular}{cccc}
\hline No. & $\begin{array}{c}\text { Kohesi } \\
\text { Leksikal }\end{array}$ & $\begin{array}{c}\text { Jumlah } \\
\text { Temuan }\end{array}$ & $\begin{array}{c}\text { Persen- } \\
\text { tase }(\%)\end{array}$ \\
\hline 1. & Pengulang- & 13 & 37,14 \\
an & an & & \\
2. & Sinonimi & 5 & 14,29 \\
3. & Hiponimi & 2 & 5,71 \\
4. & Meronimi & 1 & 2,86 \\
5. & Kolokasi & 14 & 40 \\
\hline & Jumlah & 35 & $100 \%$ \\
\hline
\end{tabular}

Pada tabel di atas, diketahui bahwa peranti kohesi leksikal yang paling banyak ditemukan adalah kolokasi, yakni sebanyak 14 bentuk atau $40 \%$. Sementara itu, peranti kohesi leksikal yang paling sedikit adalah meronimi, yakni hanya 1 bentuk atau $2,86 \%$. Contoh-contoh bentuk kohesi leksikal akan dijabarkan pada subbab berikut.

\section{Pengulangan}

Pengulangan atau repetisi merupakan peranti kohesi yang berupa penyebutan kembali kata yang telah disebutkan sebelumnya (Hasibuan, 2014: 71). Taopan menegaskan bahwa, kata yang diulang tersebut adalah kata yang menjadi kunci dan penting di dalam kalimat yang dibentuk kata tersebut (2017: 178). Contoh pengulangan dapat diamati pada kutipan berikut.

$$
\begin{gathered}
\text { Ismiyati : "Percaya bahwa aku } \\
\text { berkata benar." } \\
\text { Marsudi : "Percaya bahwa kau } \\
\text { anak yang jujur?" } \\
\text { Marsudi : "Percaya bahwa kau } \\
\text { anak yang suci?" }
\end{gathered}
$$

\author{
Marsudi : "Percaya bahwa kau \\ cinta bapakmu?" \\ (Kirdjomuljo. 2006: 33).
}

Pada kutipan dialog tersebut dijelaskan bahwa Ismiyati berusaha untuk mengembalikan kepercayaan Marsudi supaya ayahnya tersebut tidak merasa gelisah dan meragukannya lagi. Diketahui terdapat bentuk pengulangan pada kutipan dialog tersebut. Bentuk yang diulang adalah percaya bahwa. Dengan demikian, dapat dikatakan bahwa kepercayaan menjadi kata kunci pada percakapan Marsudi dan Ismiyati tersebut.

\section{Sinonimi}

Sinonimi secara harfiah memiliki artian sebuah nama lain dari dua benda yang memiliki ciri yang sama (Pateda, 2010: 222). Sementara itu, Djajasudarma menyatakan bahwa sinonimi dapat diartikan sebagai kata-kata yang memiliki kesamaan semantik yang menonjol dibandingkan perbedaannya (2013: 124). Contoh sinonimi dapat diamati pada kutipan berikut.

Ismiyati : "Percaya bahwa aku berkata benar."

Marsudi : "Percaya bahwa kau anak yang jujur?"

(Kirdjomuljo, 2006: 33).

Pada kutipan dialog tersebut dijelaskan bahwa Ismiyati berusaha untuk meyakinkan bapaknya atas kepercayaannya. Diketahui terdapat bentuk sinonimi pada kutipan dialog tersebut. Unsur yang saling bersinonimi adalah klausa berkata benar dan kata jujur. Kedua bentuk tersebut dapat saling bersinonimi karena mempunyai makna yang hampir sama/dekat yaitu sebuah bentuk sifat yang menyatapan ungkapan secara apa adanya.

\section{Hiponimi}

Hiponimi adalah suatu alat yang terdiri dari dua buah kata yang saling berhubungan secara spesifik dan generik untuk mengaitkan dua buah kalimat di dalam sebuah wacana (Chaer, 2009: 229). 
Singkatnya, hiponimi adalah hubungan kata spesifik dan kata umum (Alwi, dkk., 2003: 431).Suwandi menegaskan bahwa, Dalam relasinya, kata yang bersifat umum mengacu ke hipernim sedangkan kata yang bersifat khusus mengacu ke hiponim (2008: 142).

Siswo

\section{perlombaan}

direncanakan."

Tomo : "Perlombaan makan? Kalau ada, saya yang pertama kali akan mendaftar."

(Kirdjomuljo, 2006: 39).

Pada kutipan dialog tersebut dijelaskan tentang perlombaan yang akan diadakan pada acara dalam memperingati 17 Agustus. Diketahui terdapat hubungan hiponimi pada kutipan dialog tersebut. Unsur yang saling berhiponimi adalah kata perlombaan dan perlombaan makan. Kata pertunjukkan disebut sebagai hiponim karena bersifat umum/generik. Sementara itu, kata perlombaan makan disebut sebagai kata khusus/spesifik.

\section{Meronimi}

Meronimi adalah salah satu jenis hubungan antarmakna dalam sebuah sistem bahasa yang bersifat hierarkis dan merupakan relasi makna bagian dengan keseluruhan (Darmojuwono, 2007: 119). Djajasudarma menjelaskan bahwa, meronimi merupakan suatu hubungan inklusi yang di dalamnya unsur leksikal menggambarkan hubungan bagiankeseluruhan (2012: 88). Contoh bentuk meronimi dapat diamati pada kutipan berikut ini.

\begin{tabular}{ll} 
Suwarto & "Aku tidak akan \\
mencintai seorang pun, & \\
& \multicolumn{2}{c}{ sebelum mengetahui siapa } \\
pembunuh Mursiwi." \\
"Aku tidak akan \\
memikirkan kau, sebelum \\
tahu siapa yang \\
merencanakan \\
pembunuhan
\end{tabular}

(Kirdjomuljo, 2006:4849).

Pada kutipan dialog tersebut dijelaskan bahwa Suwarto menaruh kecurigaan kepada Ismiyati bahwa ia yang melakukan pembunuhan terhadap Mursiwi. Suwarto menegaskan untuk tidak mencintai siapa pun sebelum menemukan pembunuh istrinya. Bentuk yang saling bermeronimi adalah kata pembunuh dan kata pembunuhan. Kata pembunuh merupakan salah satu bagian yang menyusun keseluruhan proses dari sebuah peristiwa pembunuhan. Suatu peristiwa tidak dapat dikatakan sebagai pembunuhan apabila di dalamnya tidak ada pembunuh. Oleh sebab itu, pembunuh harus ada dalam peristiwa pembunuhan karena sebagai komponen wajib.

\section{Kolokasi}

Kolokasi atau sanding kata adalah kata yang saling berhubungan satu sama lain pada satu bidang atau lingkungan yang sama (Ghufron, 2012: 83). Hanafiah menyatakan bahwa kolokasi sebagai asosiasi dari semua hal (termasuk unsur bahasa) yang selalu memiliki kedekatan satu dengan yang lain dan membentuk sebuah kesatuan ( 2014: 137). Contoh bentuk kolokasi dapat diamati pada kutipan berikut ini.

$$
\begin{aligned}
\text { Suwarto } & \text { "Kalau saya } \\
& \text { menyerahkan kepada yang } \\
& \text { berwajib, bisakah polisi } \\
& \text { menangkapnya?" } \\
& \text { "Andaikan tertangkap, jika } \\
& \text { ia mempunyai pengacara } \\
& \text { yang pandai, belum tentu } \\
& \text { ia menjadi salah." } \\
& \text { (Kirdjomuljo, 2006: 38). }
\end{aligned}
$$

Pada kutipan dialog tersebut dijelaskan tentang Suwarto yang berpikir bahwa walaupun ia menyerahkan kasus pembunuhan istrinya kepada polisi, ia justru tak yakin kalau polisi dapat menangkap pelakunya. Apabila tertangkap, pelaku tersebut masih bisa selamat karena mempunyai pengacara yang pandai. 
Diketahui terdapat bentuk kolokasi pada kutipan dialog tersebut. Kata yang saling berkolokasi adalah kata polisi dan pengacara. Kedua kata tersebut dapat saling berkolokasi karena memiliki kedekatan makna yaitu dalam hal jenis pekerjaan di bidang hukum.

\section{Konjungsi}

Konjungsi adalah kategori yang menghubungkan suatu satuan bahasa dengan satuan bahasa lain yang memiliki kesetaraan, baik itu klausa dengan klausa, kalimat dengan kalimat, bahkan paragraf dengan paragraf (Chaer, 2009: 81-82) Selain itu, konjungsi juga dapat dikatakan sebagai sarana perangkai unsur-unsur kewacanaan (Mulyana, 2005: 29). Hasil temuan peranti kohesi konjungsi pada naskah drama Senja dengan Dua Kelelawar dapat diamati pada tabel 3.

Tabel 3.

Temuan Peranti Kohesi Konjungsi

\begin{tabular}{clcc}
\hline No & $\begin{array}{c}\text { Kohesi } \\
\text { Konjungsi }\end{array}$ & $\begin{array}{c}\text { Jumlah } \\
\text { Temua } \\
\text { n }\end{array}$ & $\begin{array}{c}\text { Persen- } \\
\text { tase }(\%)\end{array}$ \\
\hline 1. & $\begin{array}{l}\text { Konjungsi } \\
\text { Koordinatif }\end{array}$ & 50 & 33,33 \\
2. & $\begin{array}{l}\text { Konjungsi } \\
\text { Subordinatif }\end{array}$ & 100 & 66,67 \\
3. & $\begin{array}{l}\text { Konjungsi } \\
\text { Korelatif } \\
\text { K. }\end{array}$ & - & - \\
& $\begin{array}{l}\text { Konjungsi } \\
\text { Antarkalimat }\end{array}$ & - & - \\
\hline \multicolumn{4}{c}{ Jumlah } \\
\hline
\end{tabular}

Pada tabel hasil temuan di atas, dapat dipahami bahwa peranti konjungsi yang paling banyak ditemukan adalah konjungsi subordinatif. Sementara itu, konjungsi korelatif dan konjungsi antarkalimat tidak ditemukan selama peneliti menganalisis data. Contoh bentukbentuk konjungsi dapat diamati pada kutipan berikut ini.

Ismiyati : "Pak Sis, tadi Bapak menunggu katanya sudah lama tidak ketemu."
Siswo : "Nanti aku mampir setelah selesai."

(Kirdjomuljo, 2006: 22).

Pada kutipan dialog tersebut dijelaskan bahwa Ismiyati sedang bertemu dengan Siswo dan memberitahukan bahwa bapaknya menunggu kedatangannya karena sudah lama tidak bertemu. Siswo pun menyanggupi untuk bertemua dengan bapak Ismiyati dengan catatan ia telah selesai bekerja. Terdapat konjungsi koordinatif pada kutipan dialog tersebut.Konjungsi koordinatif adalah konjungsi yang menghubungkan dua atau lebih unsur yang memiliki status yang sama atau memiliki kedudukan yang setara (Suwandi, 2008: 136). Bentuk setelah tersebut dipakai untuk menghubungkan dan menjelaskan bahwa Siswo akan menyelesaikan pekerjaannya terlebih dahulu baru kemudian mampir ke rumah Marsudi.

Selain terdapat konjungsi kordinatif, terdapat pula konjungsi subordinatif pada naskah drama tersebut. Konjungsi subordinatif adalah konjungsi yang menghubungkan dua buah konstituen yang memiliki kedudukan tidak setara atau sederajat (Chaer, 2009: 82). Contoh bentuk konjungsi subordinatif dapat diamati pada kutipan berikut ini.

Tomo : "Istri sudah meninggal, tak bisa disesali."

"Cari yang lain kalau tidak tahan menjadi duda." (Kirdjomuljo, 2006: 18).

Pada kutipan dialog tersebut dijelaskan bahwa Tomo sebagai sahabat Suwarto memberikan nasihat kepadanya untuk mencari pengganti istrinya apabila ia sudah tidak tahan menyandang status sebagai duda. Terdapat konjungsi subordinatif pada kutipan tersebut. Bentuk kalau dipakai untuk menghubungkan dua buah klausa yaitu klausa yang menjadi syarat dengan klausa yang menjadi hasil. Jadi, dapat dipahami bahwa rasa tidak tahan menyandang status sebagai duda 
yang dirasakan Suwarto menjadi syarat untuknya agar mencari istri yang lain.

Relevansi Peranti Kohesi pada Naskah Drama Senja dengan Dua Kelelawar dengan Pembelajaran Bahasa Indonesia

Berdasarkan Permendikbud nomor 24 tahun 2016 tentang kompetensi inti dan kompetensi dasar, materi tentang peranti kohesi dalam naskah drama relevan dengan KD 3.19 dan KD 4.19 kelas XI SMA, yakni menganalisis isi dan kebahasaan drama yang dibaca atau ditonton dan mendemonstrasikan sebuah naskah drama dengan memerhatikan isi dan kebahasaan. Dari kedua kompetensi dasar tersebut, indikator keberhasilan yang harus dicapai oleh peserta didik adalah peserta didik mampu untuk mengidentifikasi isi dan kebahasaan drama yang dibaca atau ditonton. Selanjutnya, akan dijelaskan relevansi materi peranti kohesi dengan pembelajaran bahasa Indonesia di SMA.

Dilihat dari aspek perencanaan pembelajaran, peranti kohesi diperhatikan oleh guru dalam penerapan pembelajarannya. Hal tersebut dapat dilihat pada rencana pelaksanaan pembelajaran (RPP) yang dibuat oleh guru. Salah satu materi yang direncanakan untuk diajarkan adalah materi kebahasaan drama yang juga mencakup tentang peranti kohesi dalam naskah drama. Tujuan yang diharapkan guru kepada peserta didik adalah agar peserta didik dapat menemukan suatu bentuk kebahasaan seperti konjungsi, pronomina, kata penunjuk, dan lain sebagainya dalam sebuah kalimat. Menurut data dari catatan lapangan hasil wawancara dengan guru, tanpa peranti kohesi dalam suatu kalimat membuat cerita menjadi tidak runtut alurnya, sehingga sulit untuk dipahami pembaca.

Kemudian apabila dilihat pada aspek pelaksanaan pembelajaran, materi tentang peranti kohesi dalam naskah drama sudah diperhatikan oleh guru. Berdasarkan catatan lapangan hasil wawancara dengan guru, guru mengajarkan materi peranti kohesi ketika memahamkan materi konsep kepada peserta didik. Sebelum materi peranti kohesi diberikan, guru terlebih dahulu memberikan materi tentang pengertian dan unsur-unsur naskah drama. Apabila peserta didik dirasa sudah memahami materi tentang peranti kohesi, maka guru akan memberikan materi menyusun naskah drama dan pementasannya. Dengan demikian, dapat dikatakan bahwa dalam pembelajaran drama, materi tentang peranti kohesi sudah diberikan dengan baik. Oleh sebab itu, peranti kohesi dalam naskah drama Senja dengan Dua Kelelawar dapat pula diajarkan kepada peserta didik kelas XI dengan prosedur yang sama pula.

Berdasarkan hasil penelitian, temuan peranti kohesi yang dominan adalah pronomina dan konjungsi. Penggunaan pronomina dan konjungsi yang dominan dan bervariasi pada suatu karya sastra oleh pengarang memiliki tujuan tertentu. Pendapat ahli sastra yaitu Ibu Sri Hastuti, S.S, M.Pd., unsur yang sangat dominan pada karya sastra adalah penggunaan diksi atau pilihan kata. Pemakaian diksi yang bervariatif oleh penulis/pengarang bertujuan agar sebuah karya atau tulisan menjadi lebih menarik oleh pembaca sehingga tidak monoton. Selain itu, penggunaan diksi juga bertujuan agar memunculkan nilai estetis suatu karya sastra. Adanya pronomina dan konjungsi yang bervariatif tersebut merupakan sebuah pilihan kata atau diksi yang digunakan penulis. Hal tersebut sejalan dengan penelitian Saraswati, dkk., (2017: 264) yang menyatakan bahwa adanya diksi/pemilihan kata oleh penulis bertujuan untuk memeberikan variasi yang berbeda, menghemat perbendaharaan kata, dan membuat kata-kata lebih menarik. Sementara itu, hasil penelitian Supriyono, dkk., (2018: 116) menunjukkan bahwa, penyair dalam menggunakan pilihan kata sangatlah sederhana dan tidak terlalu berlebihan dan mendayu-dayu. Akan tetapi, pilihan kata tersebut dapat 
mengekspresikan sebuah curahan perasaan, sehingga dapat memunculkan nilai estetis yang tinggi.

Selain bertujuan untuk membuat suatu tulisan/karya menjadi menarik untuk dibaca, peranti kohesi juga memiliki fungsi yang penting dalam pembelajaran bahasa Indonesia, salah satunya adalah untuk meminimalisir terjadinya kesalahan berbahasa oleh peserta didik. Hal tersebut sesuai dengan penelitian Oktaviani, dkk., (2018: 90) bahwa penyebab terjadinya kesalahan berbahasa adalah adanya interferensi bahasa ibu, minimnya informasi dan referensi tentang kaidah berbahasa, kurangnya penguasaan kosakata dan pemahaman tentang kalimat efektif, dan yang paling terlihat adalah kurangnya motivasi siswa untuk belajar bahasa Indonesia. Konjungsi sebagai salah satu bentuk kosakata yang dominan sering digunakan peserta didik dalam menyusun sebuah paragraf yang padu. Peranti kohesi khususnya konjungsi penting untuk dijadikan materi kebahasaan peserta didik oleh guru kaitannya dengan unsur kebahasaan. Hal tersebut didasari penggunaan peranti konjungsi yang masih terdapat kesalahan oleh peserta didik. Oleh karena itu, penting bagi peserta didik untuk memahami bagaimana konjungsi digunakan dengan tepat dalam sebuah wacana.

Temuan peranti kohesiyang bervariasi tersebut relevan untuk diajarkan pada pembelajaran bahasa Indonesia di SMA. Materi tentang peranti kohesi memiliki relevansi dengan kompetensi dasar pada kelas X, kelas XI, dan kelas XII SMA. Pada kelas $X$, peranti kohesi relevan untuk diajarkan pada KD 3.2 dan 4.2 berkaitan dengan teks laporan hasil percobaan, KD 3.4 dan 4.4 berkaitan dengan teks eksposisi, KD 3.6 dan 4.6 berkaitan dengan teks anekdot, KD 3.8 dan 4.8 berkaitan dengan teks cerita rakyat, KD 3.11 dan 4.11 berkaitan dengan teks negosiasi, dan KD 3.15 dan 4.15 berkaian dengan teks biografi. Pada kelas XI, materi peranti kohesi relevan untuk diajarkan pada KD 3.2 dan 4.2 berkaitan dengan teks prosedur, KD 3.4 dan 4.4 berkaitan dengan teks eksplanasi, KD 3.6 dan 4.6 berkaitan dengan teks ceramah, KD 3.13 dan 4.13 berkaitan dengan proposal, KD 3.15 dan 4.15 berkaitan dengan teks karya ilmiah, dan KD 3,19 dan 4.19 berkaitan dengan drama. Sementara itu, pada kelas XII materi peranti kohesi relevan untuk diajarkan pada KD 3.2 dan 4.2 berkaitan dengan teks surat lamaran, KD 3.4 dan 4.4 berkaitan dengan novel/cerita sejarah, KD 3.6 dan 4.6 berkaitan dengan teks editorial, KD 3.9 dan 4.9 berkaitan dengan novel, KD 3.11 dan 4.11 berkaitan dengan teks artikel/buku ilmiah, dan KD 3.13 dan 4.13 berkaitan dengan kritik/esai.

\section{SIMPULAN}

Berdasarkan hasil penelitian dan analisis data, dapat disimpulkan bahwa pada naskah drama Senja dengan Dua Kelelawar ditemukan sejumlah peranti kohesi yang beragam. Pada aspek kohesi gramatikal, ditemukan bentuk pronomina, penyulihan, dan pelesapan. Temuan peran kohesi gramatikal terbanyak adalah pronomina, sedangkan temuan paling sedikit adalah penyulihan. Pada aspek kohesi leksikal ditemukan bentuk pengulangan, sinonimi, hiponimi, meronimi, dan kolokasi. Temuan peranti kohesi leksikal terbanyak adalah kolokasi, sedangkan temuan paling sedikit adalah meronimi. Pada aspek konjungsi, ditemukan bentuk konjungsi koordinatif dan konjungsi subordinatif. Penggunaan peranti kohesi yang bervariasi tersebut ada kaitannya dengan pemilihan kata atau diksi. Peranti kohesi yang termasuk diksi dipakai untuk memunculkan nilai estetika pada suatu karya sastra. Selain itu, dengan adanya diksi tersebut dapat menarik minat pembaca/penonton untuk menikmati suatu karya sastra.

Peranti kohesi yang terdapat pada naskah drama Senja dengan Dua Kelelawar karya Kirdjomuljo dapat dikatakan relevan dengan pembelajaran bahasa Indonesia di SMA. Relevansi 
tersebut dapat diketahui dari kompetensi dasar (KI) pada jenjang SMA kelas XI yakni terdapat KD 3.19 dan 4.19 yang berkaitan langsung dengan materi peranti kohesi. Dari aspek perencanaan pembelajaran, materi peranti kohesi sudah diperhatikan oleh guru untuk diajarkan kepada peserta didik melalui tujuan pembelajaran, yakni diharapkan peserta didik dapat memahami dan menemukan bentuk-bentuk peranti kohesi. Demikian juga dari aspek pelaksanaan pembelajaran, guru telah memahamkan dengan sungguh-

\section{REFERENSI}

Alwi, H., dkk. (2003). Tata Bahasa Baku Bahasa Indonesia. Edisi Ketiga. Jakarta: Balai Pustaka.

Beding, V.O. (2015). Kekerasan Struktural dan Personal dalam Naskah Drama Tumirah Sang Mucikari Karya Seno Gumira Ajidarma Tinjauan Sosiologi Sastra. Vox Edukasi, 6(2), 184-191.

Chaer, A. (2008). Morfologi Bahasa Indonesia: Pendekatan Proses. Jakarta: Rineka Cipta. (2009). Sintaksis Bahasa Indonesia: Pendekatan Proses. Jakarta: Rineka Cipta.

Darmojuwono, S. (2007). Semantik. Dalam Kushartanti, U. Yuwono, \& M.R.M.T. Lauder (Eds). Pesona Bahasa: Langkah Awal Memahami Linguistik. Jakarta: PT Gramedia Pustaka Utama.

Djajasudarma, F. (2012). Semantik 1: Makna Leksikal dan Gramatikal. Bandung: PT Refika Aditama. (2013). Semantik 2: Relasi Makna Paradigmatik, Sintagmatik, dan Derivasional. Bandung: PT Refika Aditama.

Eriyanto. (2011). Analisis Isi: Pengantar Metodologi untuk Penelitian Ilmu Komunikasi dan Ilmu-Ilmu Sosial Lainnya. Jakarta: Penerbit Kencana.

Ghufron, S. (2012). Peranti Kohesi dalam Wacana Tulis Siswa: Perkembangan sungguh materi peranti kohesi kepada peserta didik supaya dapat dipahami. Hal tersebut dikarenakan pada akhir pembelajaran drama, peserta didik harus membuat sebuah naskah drama yang mana mereka harus mengetahui kegunaan peranti kohesi agar menghasilkan naskah drama yang baik. Selain diajarkan pada pengajaran unsur kebahasaan, peranti kohesi relevan juga diajarkan pada materi kebahasaan pada semua jenis teks baik di kelas X, kelas XI, maupun kelas XII SMA

dan Kesalahannya. Bahasa dan Seni, 40(1), 81-93.

Gunawan, I. (2015). Metode Penelitian Kualitatif: Teori dan Praktik. Jakarta: Bumi Aksara.

Hanafiah, W. (2014). Analisis Kohesi dan Koherensi pada Wacana Buletin Jumat. Epigram, 11(2), 135-152.

Hasibuan, A. (2014). Analisis Piranti Kohesi dalam Wacana Tulis Ilmiah. Visipena. 5 (2). 58-76.

Miles, B.M., Huberman, A.M, \& Saldaña, J. (2014). Qualitative Data Analysis: A Methods Sourcebook. California: SAGE Publication.

Mulyana. (2005). Kajian Wacana. Yogyakarta: Tiara Wacana.

Noviastuti, L., Arifah, F.N., \& Murtiani, A. (2017). Tata Bahasa Indonesia: Pedoman Lengkap, Mudah, dan Praktis Berbahasa Indonesia. Bantul: Penerbit Araska.

Oktaviani, F., Rohmadi, M., \& Purwadi. (2018). Analisis Kesalahan Berbahasa Indonesia pada Karangan Eksposisi Siswa Kelas X MIPA (Studi Kasus di SMA Negeri 4 Surakarta). BASASTRA: Jurnal Penelitian Bahasa, Sastra Indonesia, dan Pengajarannya, 6(1), 83-93.

Pateda, M. (2010). Semantik Leksikal. Jakarta: Rineka Cipta. 
Saraswati, R., Setiawan, B., \& Purwadi. (2017). Diksi, Gaya Bahasa, dan Nilai Pendidikan Karakter dalam Lagu Grup Band Sheila On 7 sebagai Sumber Materi Ajar di Sekolah Menengah Pertama. BASASTRA: Jurnal Penelitian Bahasa, Sastra Indonesia, dan Pengajarannya, 5(2), 247-265.

Sugiyono. (2016). Memahami Penelitian Kualitatif. Bandung: Penerbit Alfabeta.

Supriyono, S., Wardani, N.E., \& Saddhono, K. (2018). Diksi Konotatif Puisi-Puisi Subagio Sastrowardoyo dan Implementasinya dalam Pembelajaran Apresiasi Sastra di SMA. Jurnal Gramatika, 4(1), 104117.

Suwandi, S. (2008). Serbalinguistik. Surakarta: UNS Press.

Taopan, L.A.T.S. (2017). Pemarkah Kohesi dalam Rubrik Tapaleuk Harian Pos Kupang. RETORIKA: Jurnal Ilmu Bahasa. 3(1), 170-187.

Wicaksono, A.B., Rakhmawati, A. \& Suhita, R. (2018). Naskah Drama Senja Dengan Dua Kelelawar Karya Kirdjomuljo: Kajian Psikologi Sastra dan Relevansinya Sebagai Bahan Ajar Apresiasi Drama di Sekolah Menengah Atas. BASASTRA: Jurnal Penelitian Bahasa, Sastra Indonesia, dan Pengajarannya, 6(1), 1-18. 